\title{
Changes in Urinary Bladder Smooth Muscle Contractility and the Role of Rho Kinase and Isoprostane after Partial Bladder outlet Obstruction in rats
}

\author{
Abeer E. Dief *, Adham R. Mohamed*, Gehan Mohamed Sharara** \\ Department of Medical Physiology* and department of Biochemistry** \\ Faculty of Medicine-Alexandria University
}

\begin{abstract}
Objective: Bladder outlet obstruction is a common urological problem that associated with many cellular changes and remodeling of urinary bladder detrusor smooth muscle. This study was designed to determine the changes in Rho kinase (ROCK) and isoprostane levels in urinary bladder homogenate after partial bladder outlet obstruction (PBOO); and to evaluate the contractile response of isolated rat detrusor muscle after PBOO. Methods: The present work was carried out on 30 male albino rats that were divided into 3 groups (10 rats/group): group I: consisted of normal rats, they were sham operated and considered as control group, group II: consisted of rats that were undergone PBOO for 14days, group III: consisted of rats that were undergone $P B O O$ for 28 days. The following parameters were assessed in rats of all groups: urinary bladder weight, levels of both Rho kinase and isoprostane in the tissues of urinary bladder as well as the contractile response of detrusor muscle both spontaneously and in response to acetyl choline. Results: The present study revealed a significant increase in the weight of urinary bladder in rats of PBOO of group II and III as compared to sham operated control of group I. There was a significant increase in the mean value of Rho kinase and isoprostane in the tissue of the urinary bladder after obstruction. 14 days after obstruction was associated with a significant increase in the mean value of Rho kinase which was significantly high compared to group I (sham operated rats) and group III (28days of obstruction), 28 days of obstruction was associated with decrease in the mean value of Rho kinase compared to 14 days of obstruction, however, its value was above the control. Regarding the contractile response, $\mathrm{PBOO}$ was associated with increased spontaneous activity of detrusor muscle and increased tonic response to acetyl choline which was significantly high after 14 and 28 days of obstruction compared to the control. Conclusion: The results of the present study demonstrated that Rho kinase and isoprostane levels were elevated after bladder outlet obstruction and that Rho kinase could play a crucial role in the regulation of rat urinary bladder smooth muscle contraction and tone. Therefore, Rho kinase inhibitors may prove to be therapeutically useful in the treatment of lower urinary tract disorders associated with changes in the physiology of bladder smooth muscle contractility.
\end{abstract}

Keywords: Urinary bladder-Obstruction- Contractility- Rho kinase- Isoprostane.

Abbreviations: PBOO: Partial bladder outlet obstruction. MLC: Myosin light chain RNOS: Reactive nitrogen and oxygen species. ROCK: Rho kinase. 


\section{INTRODUCTION}

Bladder outlet obstruction (BOO) is a common urological problem which mainly results from benign prostatic hyperplasia or congenital anomalies. It leads to an impaired ability of the bladder to store and empty urine. This dysfunction can be associated with drastic loss of smooth muscle function and bladder contractility in some cases, whereas other cases develop severely hypertrophied and hypercontractile bladder. ${ }^{(1)}$ Despite the high prevalence of $\mathrm{BOO}$, the mechanisms responsible for bladder dysfunction induced by BOO remain poorly understood and are the subject of intensive investigation. ${ }^{(2)}$

Changes in the urinary bladder contractility are one of the main pathophysiological changes accompanying bladder obstruction. ${ }^{(3)}$ Contraction and relaxation of urinary bladder smooth muscle is mediated by variation in the intracellular free calcium $[\mathrm{Ca} 2+]$. Rise in intracellular $\mathrm{Ca} 2+$ promotes binding to calmodulin (CaM), which in turn activates the phosphorylation of myosin light chain (MLC) by myosin light chain kinase (MLCK), resulting in smooth muscle contraction. Recently, however, secondary mechanisms have been identified that can modulate smooth muscle contractility independently of $\mathrm{Ca} 2+.{ }^{(4)}$ Protein kinase $\mathrm{C}$ and Rho kinase(ROCK) pathways are the two main regulatory mechanisms for inhibition of myosin light chain phosphatase (MLCP) preventing the dephosphorylation of MLC, which leads to $\mathrm{Ca} 2+$-sensitization of the smooth muscle. ${ }^{(5,6,7)}$ However; there are no definite data on the expression of ROCK or MLCK in detrusor muscle from bladders with obstruction- induced hypertrophy.

ROCKs are serine/threonine kinases of $160 \mathrm{kDa}$ that are involved in many cellular functions. Two ROCK isoforms have been identified: ROCK-I (also known as ROK $\beta$ or p160ROCK) and ROCK-II (also known as ROK $\alpha$ or Rho kinase). ROCK-I, ROCK-II and the ROCK activators are expressed in many tissues, including the urinary bladder of different species, at both the mRNA and the protein level. ${ }^{(\mathbf{8 , 9})}$ ROK $\alpha$ has $64 \%$ sequence identity with $\operatorname{ROK} \beta$ and these two isoforms share $90 \%$ in their kinase domain although the exact functional difference between these two isoforms are not clearly defined. In addition, ROCK plays role in other functions as it stimulates the phospholipid phosphatase activity of PTEN (phosphatase and tensin homologue), a human tumor suppressor protein. In this way, PTEN is important to prevent uncontrolled cell division as exhibited in cancer cells. ${ }^{(10)}$ ROCKS play a role in membrane blebbing, a morphological change seen in cells committed to apoptosis. ${ }^{(11)}$ Several studies have found that ROCK plays an important role in the regulation of rat urinary bladder smooth muscle contraction and tone. ${ }^{(\mathbf{8 , 9})}$

There is also mounting evidence that ischemia/reperfusion $(\mathrm{I} / \mathrm{R})$ is a major etiologic factor in the progression of bladder dysfunction associated with bladder outlet obstruction. I/R results in production of reactive nitrogen and oxygen species (RNOS) which likely play a 
role in the development of bladder dysfunction related to bladder outlet obstruction. ${ }^{(12)}$ The physiological consequences of cellular and subcellular membrane oxidation include decreased mitochondrial function, nerve damage and contractile dysfunction. It has been shown that oxidative stress markers were significantly increased as early as 3 days following PBOO surgery in experimental animals. Isoprostane (8iso PGF $2 \alpha$ ) is a product of oxidative stress that may causes potent smooth muscle contraction. ${ }^{(13,14)}$

A number of different animal models have been used to test hypotheses regarding the pathophysiological mechanism of overactive bladder. Partial bladder outlet obstruction in animals mimics certain aspects of overactive bladder symptomatology in humans and a large number of studies have reported changes in detrusor properties in these animal models. ${ }^{(15,16)}$ Therefore, the goal of the current study was to investigate the changes in Rho kinase and isoprostane levels in the urinary bladder tissues after partial bladder outlet obstruction (PBOO); and to evaluate the extent of contribution of Rho kinase to changes of the contractile response of isolated rat detrusor muscle after partial bladder outlet obstruction.

\section{MATERIAL \& METHODS}

\section{Animal model}

This study was conducted on 30 male albino rats (200-250gm). Ethics committee approval was obtained and all animal experiments were performed in accordance with the guidelines set out by Ethical Committee of Alexandria University. The rats were maintained in controlled environment with food and water available ad libitum under 12 hours light/ dark cycles. The animals were randomly assigned to three experimental groups (10rats/group): group I: consisted of normal healthy rats, they were sham operated and considered as control group, group II: consisted of rats that were undergone PBOO for 14days, group III: consisted of rats that were undergone $\mathrm{PBOO}$ for 28 days.

Operative procedures for creating partial bladder outlet obstruction (PBOO)

Animals were anesthetized with ketamine $(100 \mathrm{mg} / \mathrm{kg}$ body wt). After the animal was shaved and prepared under sterile conditions, a 3-French coude-tip silicone catheter was passed into the bladder, and the bladder neck and urethra were exposed via a midline and retroperitoneal incision. Partial outlet obstruction was created by passing a 2-0 silk suture around the urethra. Subsequently, the urethra and catheter were ligated and the catheter was removed. The presence of the catheter ensured that the ligature did not significantly compress the urethra. Finally, the incision was closed. Sham operated rats underwent a similar procedure with a dissection around the urethra, but without a urethral ligature. ${ }^{(2,17)}$ The bladder obstruction was maintained for 14 and 28 days in the studied rats. Data collected from sham-operated rats were used as a control.

At the time of sacrifice the urinary bladders were removed and weighted. The removed bladder 
specimens were immediately used for measurement of Rho kinase and isoprostane levels as well as strips from detrusor muscle were used for assessment of the contractile response.

\section{I-Biochemical Methods}

Urinary bladder Homogenization:

A small part of urinary bladder was dissected into approximately 1$2 \mathrm{~mm}$ pieces and they were homogenized in $7 \mathrm{ml}$ of ice-cold extraction buffer contain: (1\% Triton $\mathrm{X}-100,10 \mathrm{mmol} / \mathrm{l} \mathrm{MgSO} 4,1 \mathrm{mmol} / \mathrm{l}$ EDTA, $1 \mathrm{mmol} / \mathrm{l}$ dithiothreitol, 0.5 $\mathrm{mol} / \mathrm{l} \mathrm{NaCl}, 1 \%$ protease inhibitor cocktail, $20 \mathrm{mmol} / \mathrm{l}$ HEPES $(\mathrm{pH}$ 7.5). The homogenate was centrifuged at $1500 \mathrm{x} \mathrm{g}$ for 10 minutes to remove tissue debris. The supernatant was taken and stored at $-80{ }^{\circ} \mathrm{C}$ until being used. ${ }^{(18)}$ A modification of the method of Lowry was used for the determination of protein in the homogenate. $^{(\mathbf{1 9})}$

1- Estimation of Rho kinase levels by immunoassay. ${ }^{(20)}$

Principle of the assay: (Brought by Cell Biolabs, INC)

This assay employs quantitative enzyme immunoassay to monitor ROCK activity using its physiological substrate. It developed for detection of the specific phosphorylation of Myosin phosphatase target subunit 1 (MYPT1) at Thr696 by ROCK. A strip well microtiter plate has been precoated with a recombinant MYPT1. After incubating the substrate wells with ROCK samples $(10 \mu \mathrm{l} /$ well $)$, the phosphorylated MYPT1 has been detected by an antiphospho-MYPT1

(Thr696) antibody. A recombinant active ROCK-II is also provided as a positive control.

\section{2- Estimation of isoprostane( 8-iso-} PGF2 $\alpha$ ) levels by ELISA (OxiSelect $^{\mathrm{TM}}$ Kit). ${ }^{(21,22)}$

Cell Biolabs' 8-iso-PGF2 $\alpha$ kit is a competitive enzyme-linked immunoassay (ELISA) for determining levels of 8-iso-PGF2 $\alpha$ An antibody to 8 -iso-PGF2 $\alpha$ was incubated in pre-coated microtiter plate wells. Upon washing, 8-isoPGF $2 \alpha$ standards or treated samples $(50 \mu \mathrm{l} /$ well $)$ were mixed with an HRP conjugate and added simultaneously to the wells. The unconjugated, or free 8 -iso-PGF $2 \alpha$ and 8 -iso-PGF $2 \alpha$-HRP conjugate competes for binding to the antibody bound to the plate. After this brief incubation and wash, a substrate to the HRP is added. The HRP activity results in color development that is directly proportional to the amount of 8 -iso-PGF2 $\alpha$ conjugate bound to the plate and inversely proportional to the amount of free 8-iso-PGF $2 \alpha$ in the samples or standards. The 8-isoPGF $2 \alpha$ content in an unknown sample was determined by comparing with the known predetermined standard curve.

II- Measurement of contractile response. ${ }^{(23)}$

The bladders were removed and placed in ice-cold Kreb's solution. Bladder muscle strips, approximately $1 \mathrm{~mm} \times 5 \mathrm{~mm}$ and dissected free of fat and serosa, were placed in an organ bath of $0.2 \mathrm{ml}$ capacity and perfused at a rate of $1 \mathrm{ml} \mathrm{min-1}$ with freshly prepared Kreb's solution containing $\mathrm{NaCl} 119 \mathrm{mM}, \quad \mathrm{KCl} 4.4 \mathrm{mM}$, NaHCO3 20 mM, NaH2PO4 1.2 mM, $\mathrm{MgCl} 22.5 \mathrm{mM}$, glucose $11 \mathrm{mM}$, $\mathrm{CaCl} 22.5 \mathrm{mM}$, in distilled water $\mathrm{pH}$ 7.2 , aerated with $95 \% \mathrm{O} 2,5 \% \mathrm{CO} 2$ and warmed to $37 \mathrm{C}^{\circ}$. The two ends of 
the muscle strip were attached to an isometric force transducer (Model Letica- Panlab.S.I), the contractions were recorded using polygraph 2006, panlab S.I. The muscle strip was allowed to equilibrate for 1 hour under resting tension of $1 \mathrm{gm}$ until stable baseline was attained. The amplitude of the contractions were recorded using polygraph, calibrated as the number of small square displacement of the recording pin, and expressed in gram tension.

Bladder muscle strips from studied rats were examined for spontaneous contractile activity as well as the contractile responses of bladder muscle strips from all studied groups were examined against different concentrations of acetyl choline $\left(10^{-8}\right.$ to $\left.10^{-4} \mathrm{M}\right)$. Successive concentrations were applied at about 5 minute intervals in the same tissue. When maximal response was attained, the segments were washed and left for 10 minutes to recover baseline contraction. Muscle strips were gradually stretched to a point at which they responded maximally to acetyl choline (usually $1 \mathrm{gm}$ tension). The amplitude of contractions (gm tension) was averaged.

Statistical analysis:

Tabulation and analysis of data was done using one way analysis of variance (ANOVA). Association between different parameters was determined using Pearson's correlation coefficient $(\mathrm{r})$ and statistical significance was set at $\mathrm{P}<0.05$.

\section{RESULTS}

Partial outlet obstruction of the rat urinary bladder results in several significant changes in both the structure and function of the bladder that include:

\section{1-Bladder weight:}

Bladder weight was significantly increased by obstruction. The mean bladder weight of rats after 14 and 28 days of obstruction (group II and III) was significantly higher as compared to the sham operated control group (group I). (Table 1)

2-Expression of Rho kinase at the Protein Level in the urinary bladder tissues:

There was a significant increase in the mean values of Rho kinase in the tissue of the urinary bladder after obstruction; 14 days after obstruction was associated with a significant increase in the mean value of Rho kinase (mean $=0.0570 \pm 0.0111 \mathrm{ng} / \mathrm{mg}$ protein) which was significantly higher compared to group I (sham operated rats) and group III (28 days of obstruction), $(\mathrm{p}=0.0001) .28$ days of obstruction was associated with a significant decrease in the mean value of Rho kinase compared to14 days of obstruction, however, its value was above the control group (Table II).

\section{3-Isoprostane assay:}

As demonstrated in table II; the mean values of isoprostane was peaked at 14 days of obstruction in group II $\quad(148.48 \pm 9.7313 \mathrm{pg} / \mathrm{mg}$ protein), it was statistically significant higher compared with the other two studied groups $(p=0.0001) .28$ days of obstruction in group III was associated with increased levels of isoprostane compared with sham operated group (group I). However, 28 days of obstruction in group III was associated with significant decrease in the mean value of 
isoprostane compared to 14 days obstruction group.

Pearson's correlation was performed between the 2 studied parameters in each group separately. ( $\mathrm{n}=10 \mathrm{rat} /$ group), positive correlation was found between Rho kinase and isoprostane in the three studied groups ; $(r=0.967)(p=0.0001)$. (Fig. I)

4-Contractile response of detrusor muscle:

a. Spontaneous activity:

Muscle strips from rat bladder showed significant increase in the amplitude of spontaneous contraction after PBOO compared to control group ; such increase was more after 14 days obstruction (mean $=1.95 \pm 0.211$ ) than 28 days obstruction group (mean = $1.88 \pm 0.169)$. However such difference was not statistically significant.

(Ach).

b. Response to acetyl choline

Administration of Ach produced concentration dependent increase in the force of contraction in the control group starting with a low concentration of acetylcholine, increasing gradually with the maximal response developed to $100 \mu \mathrm{m}$ Ach. However, bladder outlet obstruction for 14 or 28 days was associated with significant increase in the sensitivity to Ach, where greater concentration of Ach was associated with significant increase in the amplitude of contraction. (Table III) (Figure 2).

Table1. Bladder weight in the different studied groups.

\begin{tabular}{|l|l|}
\hline Group & Bladder weight (Gm) \\
\hline Group I (sham operated) & $0.109 \pm 0.005^{*}$ \\
\hline Group II (14 days of obstruction) & $0.174 \pm 0.024^{*}$ \\
\hline Group III (28 days of obstruction) & $0.242 \pm 0.035^{*}$ \\
\hline
\end{tabular}

$* P<0.05$.

Table II: Rho kinase (ng/mg protein) and isoprostane levels (pg/mg protein) in the different studied groups.

\begin{tabular}{|c|c|c|c|c|}
\hline Studied parameters & $\begin{array}{l}\text { Group I } \\
\text { "sham operated } \\
\text { control group" }\end{array}$ & $\begin{array}{l}\text { Group II } \\
\text { "14 days of } \\
\text { obstruction" }\end{array}$ & $\begin{array}{l}\text { Group III } \\
\text { "28 days of } \\
\text { obstruction" }\end{array}$ & $\begin{array}{l}\text { ANOVA, } \\
\text { p }\end{array}$ \\
\hline \multicolumn{5}{|l|}{$\begin{array}{l}\text { Rho kinase (ng/mg } \\
\text { protein) }\end{array}$} \\
\hline Range & $0.006-0.0074$ & $0.0420-0.0750$ & $0.0190-0.0220$ & 162.7 \\
\hline Mean \pm S.D. & $0.0069 \pm 0.0004^{\mathrm{a}}$ & $0.0570 \pm 0.0111^{b}$ & $0.0201 \pm 0.0011^{\mathrm{c}}$ & $0.0001 *$ \\
\hline \multicolumn{5}{|l|}{$\begin{array}{l}\text { Isoprostane }(\mathrm{pg} / \mathrm{mg} \\
\text { protein) }\end{array}$} \\
\hline range & $92.0-97.80$ & $135.90-165.20$ & $105.30-126.80$ & 135.4 \\
\hline Mean \pm S.D. & $95.59 \pm 1.6783^{\mathrm{a}}$ & $148.48 \pm 9.7313^{b}$ & $114.97 \pm 7.8131^{\mathrm{c}}$ & $0.0001 *$ \\
\hline
\end{tabular}

* Means significant. - Same letters means not significant. 
Table III: Comparison between the three studied groups regarding contractile response

\begin{tabular}{|c|c|c|c|c|}
\hline & $\begin{array}{l}\text { Group I } \\
\text { "Sham operated } \\
\text { control group" }\end{array}$ & $\begin{array}{l}\text { Group II } \\
\text { "14 days of } \\
\text { obstruction" }\end{array}$ & $\begin{array}{l}\text { Group III } \\
28 \text { days of } \\
\text { obstruction" }\end{array}$ & $\begin{array}{l}\text { ANOVA, } \\
\text { p }\end{array}$ \\
\hline $\begin{array}{l}\text { Spontaneous } \\
\text { contractions (gm } \\
\text { tension) } \\
\text { Range } \\
\text { Mean } \pm \text { S.D. }\end{array}$ & $\begin{array}{l}0.6-1.2 \\
0.865 \pm 0.0163^{\mathrm{a}}\end{array}$ & $\begin{array}{l}1.62-2.52 \\
1.95 \pm 0.211^{\mathrm{b}}\end{array}$ & $\begin{array}{l}1.65-2.45 \\
1.88 \pm 0.169^{b}\end{array}$ & $\begin{array}{l}12.65 \\
0.013 *\end{array}$ \\
\hline $\begin{array}{l}\text { Response to } \\
\text { aceytlcholine } \\
\text { (gm tension) } \\
\text { Range } \\
\text { Mean } \pm \text { S.D. }\end{array}$ & $\begin{array}{l}2.1-2.4 \\
2.22 \pm 0.065^{\mathrm{a}}\end{array}$ & $\begin{array}{l}3.1-3.8 \\
3.45 \pm 0.022^{b}\end{array}$ & $\begin{array}{l}3.1-3.9 \\
3.60 \pm 0.107^{\mathbf{b}}\end{array}$ & $\begin{array}{l}19.85 \\
0.011 *\end{array}$ \\
\hline
\end{tabular}

* Means significant. - Same letters means not significant.

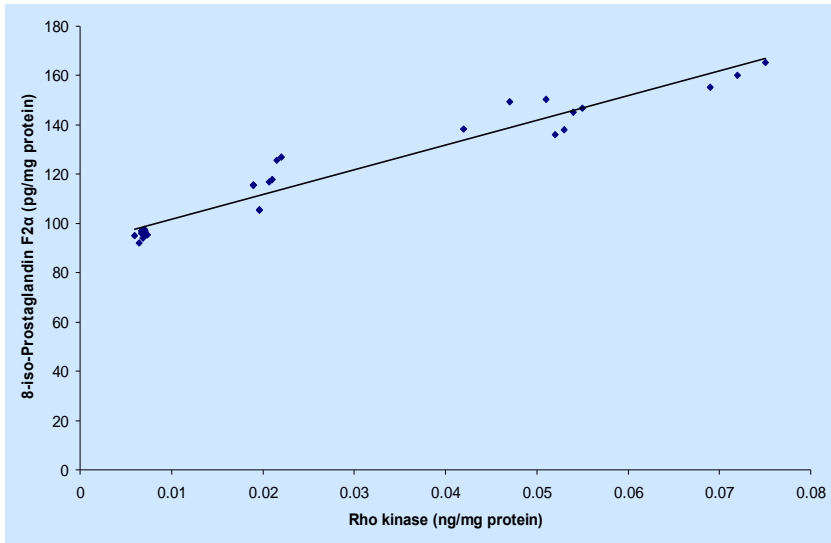

Fig. 1: Correlation between Rho kinase and isoprostane levels in the different studied groups.

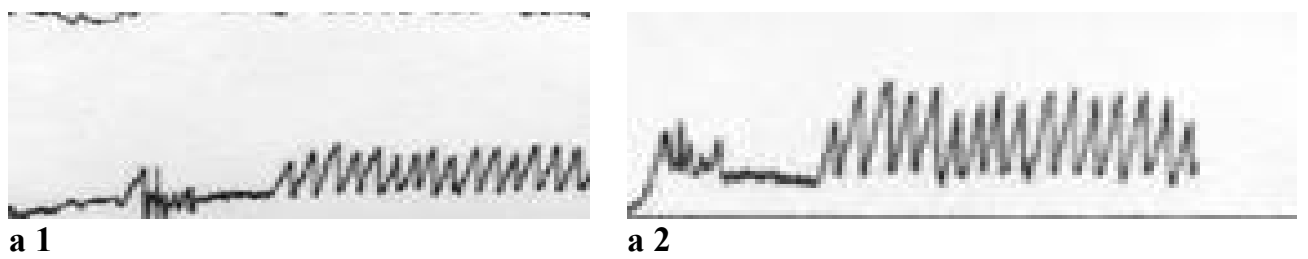

Fig. 2: Contractile response of urinary bladder smooth muscle. a1. Spontaneous contractions after PBOO. a2. Contractions in response to acetylcholine after PBOO 


\section{DISCUSSION}

Bladder outlet obstruction is a common urologic problem associated with numerous and substantial changes in the urinary bladder smooth muscle including altered smooth muscle contractility. Initially there is enlargement in bladder mass accompanied by smooth muscle hypertrophy. These hypertrophic changes allow the bladder to temporarily counteract the resistance of the obstruction. Eventually, however, the bladder detrusor function deteriorates and the obstructed bladder undergoes decompensation, a process associated with the loss of smooth muscle function. ${ }^{(24)}$ The present study focused on the role of Rho kinase and isoprostane after partial bladder outlet obstruction (PBOO) in rats as well as the effect of Rho kinase on detrusor smooth muscle contractility after PBOO.

The current results found an incremental change in Rho kinase with a different pattern after obstruction; there was a significant increase of Rho kinase contents 14 days after obstruction; however, prolonged duration of obstruction up to 28 days was associated with significant decrease in the Rho kinase contents. The previous findings were in agreement with a subsequent study by Takahashi et al. ${ }^{(\mathbf{2 5})}$ they found an increase in the expression of RhoA, ROK $\alpha$, and ROK $\beta$ after 4 weeks of bladder outlet obstruction in male rats. similarly, Aydin et al. ${ }^{(26)}$ reported an approximately two folds increase in the expression of both of these ROK isoforms in male rats after 2 weeks of
BOO consistent with the above studies Lin and colleagues ${ }^{(27)}$ had studied the effect of different duration of obstruction on corpus cavernosum smooth muscle of rabbit; they reported that 4 weeks of obstruction was associated with over expression of both isoforms which decreased significantly after 8 weeks of obstruction.

Expression of both ROK isoforms was intensely studied by many researchers. The changes in the Rho kinase isoforms during bladder obstruction appear to differ between animal species. In obstructed rabbit urinary bladder 2 weeks of obstruction was associated with over expression of Rho kinase $\beta$ while Rho kinase $\alpha$ was unchanged. ${ }^{(28)}$ However, Guven et al. ${ }^{(29)}$ examined the expression of ROK up to 8 weeks of obstruction which demonstrated that ROK $\alpha$ was increased whereas ROK $\beta$ was decreased at both protein and mRNA levels. It has been suggested that the Rho kinase isoforms can have different cellular functions.

It was found that the duration of obstruction is not the only factor which affects the expression of Rho isoforms but the age of rats could play a role in that as shown by Guven et al; ${ }^{(30)}$ In young rabbits, the expression of ROK $\alpha$ increased in 1 to 7 days in obstructed groups and decreased in the 14 days, while it increased progressively in the old rabbits, both at the mRNA and protein levels. There was a significant decrease in the expression of $\mathrm{ROK} \beta$ in young obstructed rabbits, which gradually decreased during the course of 1-7 days obstruction period and increased after 14 days of obstruction. In old 
groups, there was a decrease in expression after 1 day of obstruction and values remained at a decreased level throughout the course of the study. Therefore, this pattern of upregulation of $\mathrm{ROK} \alpha$ and down regulation of $\operatorname{ROK} \beta$ may be attributed to the faster adaptive changes of young rabbit bladder.

The increase of bladder weight is a major alteration in all models of bladder obstruction. We have observed that after 4 weeks of partial obstruction, bladder weight in the animals of obstructed group was 2 times higher than in control group. This fact could occur due to the presence of hypertrophy and hyperplasia of vesical wall. ${ }^{\text {(31) }}$

Moreover, the present study demonstrated changes in the detrusor muscle contractility after obstruction in the form of increase in the amplitude of spontaneous contraction after different durations of obstruction with increased sensitivity to increasing dose of acetylcholine. The role of spontaneous contractions was studied by Akino ${ }^{(32)}$ who reported that spontaneous detrusor muscle contractions might participate in the generation of overactive bladder syndrome.

$\mathrm{Su}$ et al. ${ }^{(33)}$ reported that smooth muscle of the rabbit urinary bladder undergoes significant functional alterations in response to partial outlet obstruction, the most striking of these alterations is the significant increase in spontaneous phasic activity and significantly enhanced sustained response which make the detrusor muscle difficult to relax, such enhanced sustained components may be also physiologically important during more prolonged micturition in bladder with urinary outflow obstruction. They attributed such changes to the effect of obstruction that induce numerous changes in contractile protein isoforms, changes in expression levels of contractile regulatory proteins. Several studies have shown that after partial bladder outlet obstruction, the primary isoform of myosin in the smooth muscle cells changes from SM-B to SM-A The SM-A isoform of myosin is characterized by a slower actinactivated myosin ATPase activity. ${ }^{(34)}$ Moreover, changes in calcium handling in the bladder smooth muscle cell was observed. These numerous and widespread changes may be compensatory in nature and important in maintaining bladder function to face the obstruction. ${ }^{(35)}$

The significant decrease in the relaxation response to acetylcholine or electrical field stimulation was also observed in corpus cavernosum smooth muscle of PBOO rabbit and the reversal of obstruction was associated with time dependent increase in response to acetylcholine or electrical field stimulation. ${ }^{\text {(27) }}$

The mechanisms involved in the altered cholinergic responses of the hypertrophic bladder are matter of debate; several researches had focused on the integrated action of Rho kinase and protein kinase $\mathrm{C}$ signaling pathways. Contraction and relaxation of the urinary bladder smooth muscle involves both electromechanical coupling where changes in membrane potential affects intracellular calcium and pharmaco-mechanical coupling where receptor activation increases calcium and recruits calcium 
sensitization pathways. It was reported that the Rho kinase modulation of the urinary bladder force is most likely to be attributable to calcium sensitization with increase in intracellular calcium that affect the electromechanical coupling. (36)

The Rho kinase mediated increase in calcium sensitivity may alter the balance between MLCK and phosphatase activities, previous results showed that the basal level of MLC phosphorylation is elevated in bladder smooth muscle of obstructed animal compared with control, which may be responsible for increased spontaneous activity in obstructed bladder. ${ }^{(33)}$

Rho kinase inhibitor (Y-27632) was found to causes a significant decrease in bladder tension and it attenuated the $\mathrm{PBOO}$ related detrusor overactivity in rats. ${ }^{(37)}$ On the basis of these considerations one can speculate from a therapeutic perspective that, Rho kinase inhibition would preferentially target the pathological phasic activity rather than inhibit the physiological receptor mediated bladder emptying and therefore appear to be a novel strategy for the management of bladder overactivity. ${ }^{(38)}$

The current study had also focused on the role of oxidative stress in the pathophysiology of PBOO; the level of isoprostane (8-iso PGF2alpha) as a product of oxidative stress was significantly increased after 14 days of obstruction and declined by more prolonged duration of obstruction to 28 days. Several authors had published that the production of free radicals is remarkable secondary to $\mathrm{PBOO}$.
Nitrotyrosine, which has been demonstrated to be a marker of free radical damage due to reactive nitrogen species (RNS), has been shown to be significantly elevated with $\mathrm{PBOO}$

The production of free radicals following $\mathrm{PBOO}$ is attributed to ischemia and reperfusion which accompanying the obstruction. It has been shown that during bladder emptying, the increased intra-wall tension results in blood vessels compression, decreased blood flow and tissue hypoxia. Although these changes occur in normal bladder, the extent of effects is significantly exaggerated in obstructed hypertrophied bladder. Both reactive oxygen species and reactive nitrogen species are generated following the cycles of I/R. ${ }^{(40)}$

Reactive oxygen species (ROS) has been shown to activate the ROK pathway as Jin et al; 2004 (41) demonstrated that the ROK signaling pathway is activated by ROS in rat aorta. Since the over distensioninduced oxidative stress in rat bladders is associated with ROS production, ROS-induced ROK activation may be intimately involved in bladder smooth muscle function and dysfunction.

It has been shown that the rabbit bladder synthesizes isoprostane and releases it to the urine. Production of isoprostane in the bladder increases with nerve stimulation-induced contraction. Exogenous isoprostane causes significant bladder smooth muscle contraction. The excitatory effect of 8-iso PGF2-alpha on smooth muscle contraction is mediated through a receptor coupled to tyrosine 
kinase(s) and Rho-kinase, but not through mobilization of $\mathrm{Ca} 2+$. Instead, they would seem to increase the sensitivity of the contractile apparatus to $\mathrm{Ca} 2+$ such that even basal levels of $[\mathrm{Ca} 2+]$ are sufficient to produce contraction. ${ }^{(42)}$

In conclusion, the results of the present study demonstrated that Rho kinase is expressed normally in the rat urinary bladder and elevated after bladder outlet obstruction and that Rho kinase plays a role in the regulation of rat urinary bladder smooth muscle contraction and tone. Therefore, Rho kinase inhibitors may prove to be therapeutically useful in the treatment of lower urinary tract disorders associated with changes in the physiology of bladder smooth muscle contractility. The reactive oxygen species isoprostane (8-iso PGF2-alpha) may play a role in the detrusor muscle overactivity accompanying the obstruction. However, much still remains to be elucidated about the RhoA/ROK pathway in detrusor dysfunction including whether true functional differences exist between $\mathrm{ROK} \alpha$ and ROK $\beta$, which may be extremely important in generating some type of isoform-selective inhibitors, In addition, there are still many discrepancies between different species with regard to ROK function.

\section{REFERENCES}

1. Juan YS, Chuang SM, Jang MY, Hsiung Huang C, Her Chou Y, Wu WJ, Long C. Basic Research in Bladder Outlet Obstruction. Incont Pelvic Floor Dysfunction. 2011; 5(1):1-6.
2. Yanagi K. Effects of Nitric Oxide on Bladder Outlet Obstruction in Rats. Yonago Acta medica 2002;45:19-26.

3. Wein AJ, Rackley RR. Overactive bladder: a better understanding of pathophysiology, diagnosis and management. J. Urol. 2006; 175: $5-10$.

4. Horowitz A, Menice CB, Laporte R, Morgan KG. Mechanisms of smooth muscle contraction. Physiol. Rev. 1996; 76: 967- 1003.

5. Somylo AP, Somylo AV. Signal transduction by G- proteins, Rho kinase and protein phosphatase to smooth muscle and non-muscle myosin II. J. Physiol. 2000; 522: 177- 85.

6. Takahashi R, Nishimura J, Hirano K, Seki N, Naito S, Kanaide H. $\mathrm{Ca} 2+$ sensitization in contraction of human bladder smooth muscle. J. Urol. 2004; $172: 748-52$.

7. Jezior JR, Brady JD, Rosenstein DI, McCammon KA, Miner AS, Ratz PH. Dependency of detrusor contractions on calcium sensitization and calcium entry through LOE-908 sensitive channels . Br. J. Pharmacol. 2001; 134: $78-87$.

8. Chang S, Hypolite JA, DiSanto ME, Changolkar A, Wein AJ, Chacko S. Increased basal phosphorylation of detrusor smooth muscle myosin in alloxan-induced diabetic rabbits mediated by up-regulation of Rho-kinase beta and CPI-17. Am. 
J. Physiol. Renal Physiol. 2006; 290:650-6.

9. Wibberley A, Chen Z, Hu E, Paul Hieble J, Westfall $T$. Expression and functional role of Rho-kinase in rat urinary bladder smooth muscle. Br. J. Pharmacol. 2003; 138: $757-66$.

10. Li Z, Dong $X$, Wang $Z$, Liu W, Deng N, Ding Y, Tang L, Hla T, Zeng R, Li L, Wu D. Regulation of PTEN by Rho small GTPases. Nat Cell Biol 2005; 4: 399-404.

11. Riento K, Ridley AJ. Rocks: multifunctional kinases in cell behaviours. Nat. Rev. Mol. Cell. Biol. 2003; 4: 446-56.

12. de Jongh $R$, Dambros $M$, Haenen GR, den Hartog GJ, Bast A, van Kerrebroeck PE, van Koeveringe GA. Partial bladder outlet obstruction reduces the tissue antioxidant capacity and muscle nerve density of the guinea pig bladder. Neurourol Urodyn 2009;28:461-7.

13. Conners W, Whitebeck C, Chicester P, Legget R, Lin AD, Johnson A, Kogan B, Levin R, Mannikarottu A. L-NAME, a nitric oxide synthase inhibitor, diminishes oxidative damage in urinary bladder partial outlet obstruction. Am. J.Physiol. Renal Physiol. 2006; 290: 357-63.

14. Tarcan T, Siroky MB, Krane RJ, Azadzoi KM. Isoprostane 8epi PGF2alpha, a product of oxidative stress, is synthesized in the bladder and causes detrusor smooth muscle contraction. Neurourol. Urodyn. 2000; 19: 43-51.

15. McMurray G, Casey JH, Naylor A. Animal models in urological disease and sexual dysfunction. Br.J.Pharmacol. 2006; 147: 62 - 79 .

16. Andersson KE, Arner A. Urinary bladder contraction and relaxation: physiology and pathophysiology. Physiol.Rev. 2004; 84 : 935 - 86.

17. Ghafar MA, Anastasiadis AG, Olsson LE, Chichester P, Kaplan SA, Buttyan R, Levin RM. Hypoxia and angiogenic response in the partially obstructed rat bladder. Lab. Invest. 2002; 82: 903-9.

18. Ripoche V, Beauwens $R$, Bouisset M, Amar-Costesec A, Beaufay H. Subcellular fractionation of epithelial cells from toad urinary bladder. Assay of marker enzymes and differential centrifugation. Biol. Cell 1989;66:107-13.

19. Lowry OH, Rosebrough NJ, Farr AL, Randall RJ. Protein measurement with the folin phenol reagent. J. Biol. Chem. 1951; 193: 265-75.

20. Rao PV, Deng PF, Kumar J. Epstein DL. Modulation of aqueous humor outflow facility by the Rho kinase specific inhibitor Y-27632. Invest Ophthalmol Vis. Sci. 2001;42: 1029-37.

21. Hozawa A, Ebihara S, Ohmori K, Kuriyama S, Ugajin T, Koizumi Y, Suzuki Y, Matsui T, Arai H, Tsubono Y, Sasaki H, Tsuji I. Increased plasma 8isoprostane levels in hypertensive subjects: the Tsurugaya Project. Hypertens. Res. 2004;27(8):55761. 
22. Morrow JD. Quantification of isoprostanes as indices of oxidant stress and the risk of atherosclerosis in humans. Arterioscler Thromb. Vasc. Biol. 2005;25(2):279-86.

23. England RC, Norman RI, Elliott RA. Direct inhibition of rat detrusor muscle contraction by erythromycin. Neurourol Urodyn. 2004;23(3):273-9.

24. Bouchelouche $K$, Andersen L, Alvarez S, Nordling $\mathbf{J}$, Bouchelouche P. Increased contractile response to phenylephrine in detrusor of patients with bladder outlet obstruction: effect of the alphala and alphald-adrenergic receptor antagonist tamsulosin. J.Urol. 2005; 173:657-61.

25. Takahashi N, Shiomi H, Kushida N, Liu F, Ishibashi K, Yanagida $\mathbf{T}$, Shishido $\mathbf{K}$, Aikawa K, Yamaguchi $\mathbf{O}$. Obstruction alters muscarinic receptor-coupled RhoA/Rhokinase pathway in the urinary bladder of the rat. Neurourol Urodyn 2009; 28:257-62.

26. Aydin M, Downing K, Villegas G, Zhang X, Chua R, Melman A, DiSanto ME. The sphingosine-1-phosphate pathway is upregulated in response to partial urethral obstruction in male rats and activates RhoA/Rho-kinase signalling. BJU Int. 2010; 106:562-71.

27. Lin WY, Mannikarottu A, Chichester P, Neuman P, Johnson A, Perez-Martinez FC, Levin RM. The effect of chronic partial bladder outlet obstruction on corpus cavernosum smooth muscle and Rho kinase in rabbits. Neurourol. Urodyn. 2008; 27:826-31.

28. Bing W, Chang S, Hypolite JA, DiSanto ME, Zderic SA, Rolf L, Wein AJ, Chacko S. Obstruction-induced changes in urinary bladder smooth muscle contractility: a role for Rho kinase. Am. J. Physiol. Renal Physiol. 2003; 285:990-7.

29. Guven A, Onal B, Kalorin C, Whitbeck C, Chichester P, Kogan B, Levin R, Mannikarottu A. Long term partial bladder outlet obstruction induced contractile dysfunction in male rabbits: A role for Rho kinase. Neurourol Urodyn 2007; 26:1043-9.

30. Guven A, Lin WY, Neuman P, Kogan BA, Levin R, Mannikarottu A. Effect of age on the role of Rho kinase in shortterm partial bladder outlet obstruction. Urology 2008; 71(3):541-5.

31. Schröder A, Chichester P, Kogan BA, Longhurst PA, Lieb J, Das AK, Levin RM. Effect of chronic bladder outlet obstruction on blood flow of the rabbit bladder. J Urol. 2001; 165: 640-6.

32. Akino H. Spontaneous contractile activity of the detrusor muscle and its role in the pathogenesis of overactive bladder syndrome. LUTS 2012; 4: 42-7.

33. Su X, Stein R, Stanton $M$, Zderic S, Robert S. Moreland R. Effect of partial outlet obstruction on rabbit urinary bladder smooth muscle function. 
Am. J. Physiol. Renal Physiol. 2003; 284: 644-52.

34. Hypolite JA, DiSanto ME, Zheng Y, Chang S, Wein AJ, and Chacko S. Regional variation in myosin isoforms and phosphorylation at the resting tone in urinary bladder smooth muscle. Am. J. Physiol. Cell Physiol 2001; 280: 254-64.

35. Stein R, Hutcheson JC, Krasnopolsky L, Canning DA, Carr MC, and Zderic SA. The decompensated detrusor. V. Molecular correlates of bladder function after reversal of experimental outlet obstruction. J. Urol. 2001; 166: 651-7.

36. Somlyo AP, Somlyo AV. Ca $2+$ sensitivity of smooth muscle and non-muscle myosin II: modulated by $\mathrm{G}$ proteins, kinases, and myosin phosphatase. Physiol .Rev. $2003 ; 83: 1325$ - 58.

37. Kim HW, Cho SY, Park DJ, Yoon B, Lee JY. Effects of Rho kinase inhibitor on detrusor overactivity after bladder outlet obstruction in rats. Korean J. Urol. 2007;48:832-7.

38. Boberg L, Polijakovic M, Rahman A, Eccles R, Arner A. Role of Rho kinase and protein kinase $\mathrm{C}$ during contraction of hypertrophic detrusor in mice with partial urinary bladder outlet obstruction. BJUI 2011; 109: 132-40.

39. Levin RM, Agartan CA, Leggett RE. Effect of partial outlet obstruction on nitrotyrosine content and distribution within the rabbit bladder. Mol. Cell Biochem. 2005; 276(1-2):143-8.

40. Valko M, Leibfritz $D$, Moncol J, Cronin MT, Mazur M, Telser J. Free radicals and antioxidants in normal physiological functions and human disease. Int. J. Biochem. Cell Biol. 2007; 39:4484.

41. Jin $L$, Ying $Z$, Webb RC. Activation of Rho/Rho kinase signaling pathway by reactive oxygen species in rat aorta. Am. J. Physiol Heart Circ. Physiol. 2004; 287:1495-1500.

42. Janssen LJ, Premji M, Netherton S, Coruzzi J, LuChao H, Cox PG. Vasoconstrictor actions of isoprostanes via tyrosine kinase and Rho kinase in human and canine pulmonary vascular smooth muscles. Br. J. Pharmacol 2001; 132: 127-34. 


\title{
التغيرات التى تحدث فى العضلات الملساء للمثانة البولية و دور انزيم التئي الروكاينز و الايزوبروستان بعد الانسداد الجزئى لمخرج البول البولئ فور الفئران
}

\author{
عبير الإمام ضيف ـ ادهم راشد محمد - بيهان محد شرارة
}

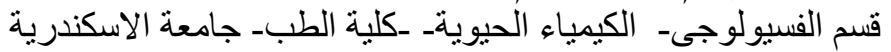

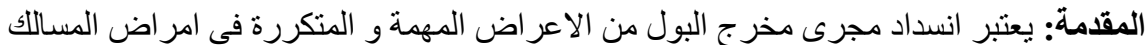

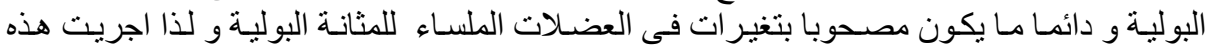

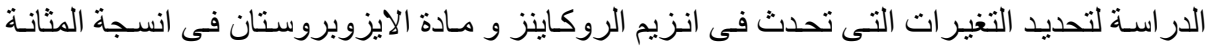

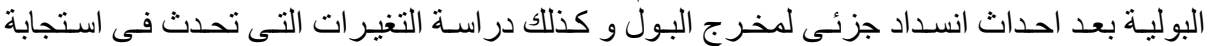
العضلات الملساء لهذا الانسداد. ت العداد

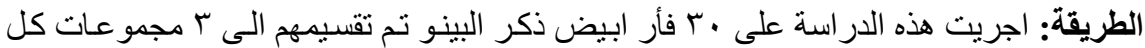

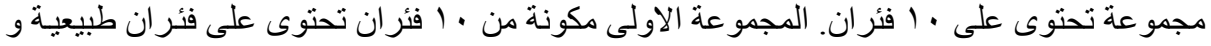

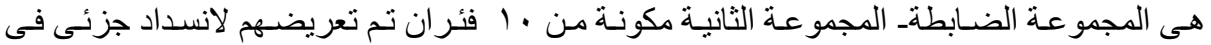

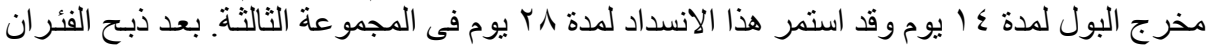

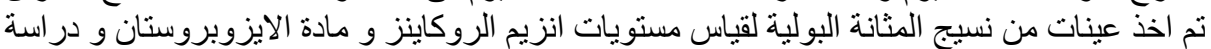
انقباضات العضلات الملساء التلقائية و كذلك بعد استخدام عقار الاستيل كولين لتحفيز العضلات التيلات

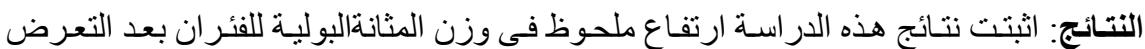

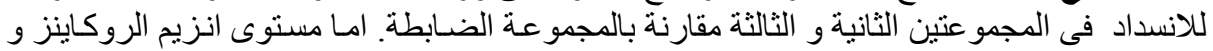

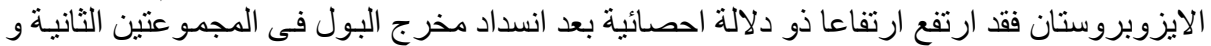

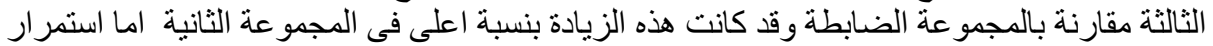

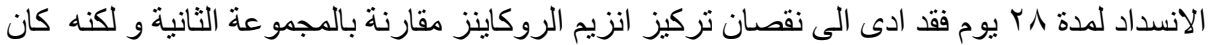

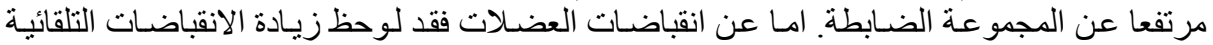

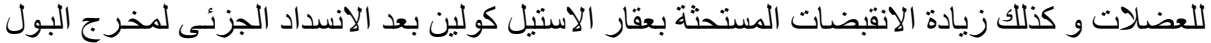

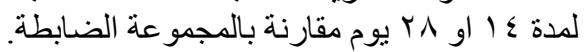

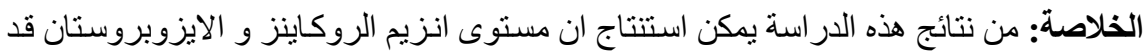

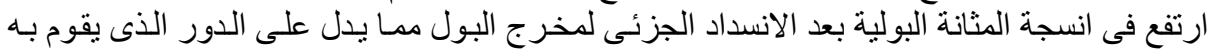

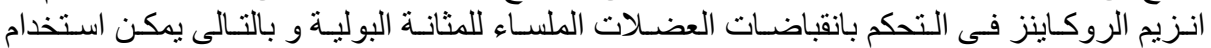

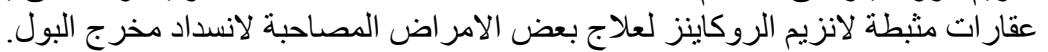


